TAPROBANICA, ISSN 1800-427X. May, 2020. Vol. 09, No. 01: pp. 3-11, pls. 1-3. (C) Research Center for Climate Change, University of Indonesia, Depok, Indonesia www.taprobanica.org

\title{
REDISCOVERY OF MODIGLIANI'S NOSE-HORNED LIZARD, Harpesaurus modiglianii VINCIGUERRA, 1933 (REPTILIA: AGAMIDAE) AFTER 129 YEARS WITHOUT ANY OBSERVATION
}

\section{Chairunas A. Putra ${ }^{1,7}$, A.A. Thasun Amarasinghe ${ }^{2,7}$, Desy Hikmatullah ${ }^{1,7}$, Stefano Scali ${ }^{3}$, JanJaap Brinkman ${ }^{4}$, Ulrich Manthey ${ }^{5} \&$ Ivan Ineich $^{6}$}

${ }^{1}$ Herpetologer Mania (Amphibian \& Reptilian Conservation Community in Sumatra), Jl. Dahlia No. 6 Medan, North Sumatra, Indonesia

${ }^{2}$ Research Center for Climate Change, University of Indonesia, Gd. PAU Lt. 8.5, Kampus UI, Depok 16424, Indonesia

${ }^{3}$ Museo Civico di Storia Naturale di Milano, Corso Venezia, 55, Milano 20121, Italy

${ }^{4}$ Deltares, P.O. Box 1772600 MH Delft, The Netherlands

${ }_{6}^{5}$ Society for Southeast Asian Herpetology, 12249 Berlin, Germany

${ }^{6}$ Muséum National d'Histoire Naturelle, Sorbonne Universités, Institut de Systématique, Évolution et Biodiversité, UMR 7205 (MNHN/CNRS/UPMC/EPHE), 57 rue Cuvier, F-75005 Paris, France

${ }^{7}$ Association of Asian Herpetology (Asosiasi Herpetologi Asia), Jl. BSD Bintaro No. 88, Pondok Aren 15228, Tangerang Selatan, Indonesia

${ }^{2}$ Corresponding author. E-mail: thasun@rccc.ui.ac.id

\begin{abstract}
The Modigliani's nose-horned lizard, Harpesaurus modiglianii Vinciguerra, 1933, is one of the rarest lizards in the world, known only from its single type specimen collected in 1891, from North Sumatra, Indonesia. During explorations of the forests surrounding Lake Toba and its caldera, we discovered a population of $H$. modiglianii at an elevation of $1,675 \mathrm{~m}$ a.s.l., and provide the first data on its habitat. We here re-describe the species based on an examination of its type and new material, and provide an English translation of the complete original description which was originally written in Italian.
\end{abstract}

Key words: Living population, Toba Caldera, Northern Sumatra, Indonesia, elevation forest.

\section{Introduction}

The herpetological diversity of Sumatra remains substantially underexplored despite being the sixth largest island in the world and certainly the home of extremely diverse biota, among which are many endemics (Iskandar et al. 2017). Few herpetofaunal species have been added to this island's list since World War II (Iskandar \& Mumpuni 2004): only sixteen species of lizards were described from mainland Sumatra during the last decade and half of them were agamid lizards (Amarasinghe et al. 2015, Iskandar et al. 2017, Grismer et al. 2014, Harvey et al. 2014, 2015, 2017a,b, 2018). With the exception of 
Dendragama diodema, all of the new agamid lizards discovered during the last decade in Sumatra originated from the southern and southwestern parts of the Island (see Harvey et al. 2017b), reflecting a lack of survey effort in the island's north and centre.

The delimitation and content of the genus Harpesaurus - most species of which are known from small numbers of specimens - is not fully understood (Parker 1924, King 1978, Moody 1984, Böhme 1989, Lardner et al. 2010). A.H.A. Duméril in A.M.C. Duméril \& A.H.A. Duméril (1851) described the first nose-horned lizard species (most likely from Java Island, Indonesia) and placed it within his newly described monotypic genus Arpephorus as A. tricinctus. Subsequently Boulenger (1885) synonymised the genus Arpephorus with a new genus Harpesaurus because the generic name Arpephorus was preoccupied by Arpephorus Stephens, 1829 for a Coleopteran genus (Insecta).

Mertens (1924) described a new genus Hylagama, in which he placed his new species Hylagama borneensis collected from Central Borneo.

A similar species, Harpesaurus thescelorhinos King, 1978, was described from the Niah and Kapit areas of Sarawak, 100-200 $\mathrm{km}$ from the type locality of Hylagama borneensis. King (1978) did not compare his Harpesaurus species with Hylagama borneensis, probably because it was listed within another genus. Moody (1984) strongly argued that the genus Hylagama should be retained as a valid monotypic genus [with Hylagama borneensis] and synonymised Harpesaurus thescelorhinos within Hylagama borneensis. Furthermore Moody (1984) considered the holotype of Hylagama borneensis as lost and designated FMNH 138196 erroneously as a lectotype (must be neotype) to replace the lost holotype of Hylagama borneensis. Schlüter \& Hallermann (1997) rediscovered the holotype (SMNS 4596) of Hylagama borneensis in the herpetology collection at Staatliches Museum für Naturkunde in Stuttgart, hence invalidating Moody's (1984) neotype designation. Manthey (2010) considered Hylagama borneensis as belonging to the genus Harpesaurus.

Another nose-horned lizard was described by Parker (1924), who placed it in a new genus Thaumatorhynchus. Later, Vinciguerra (1933) and Wermuth (1967) synonymised the genus Thaumatorhynchus with Harpesaurus due to minor morphological differences between the two. Even though Teynié et al. (2010) placed Thaumatorhynchus brooksi again within its former genus, we follow Wermuth (1967) and place that species in the genus Harpesaurus. Manthey (2010) published the first images of a living specimen of $H$. brooksi, and also followed the taxonomic placement of Wermuth (1967).

As treated here, the genus Harpesaurus consists of six species: $H$. beccarii Doria, 1888 , H. brooksi (Parker, 1924) and H. modiglianii Vinciguerra, 1933 from Sumatra; $H$. ensicauda Werner, 1913 from Nias Island; H. tricinctus (A.H.A. Duméril, 1851) presumably from Java, and H. borneensis (Mertens, 1924) from Borneo. The Modigliani's nose-horned lizard is one of the rarest lizards in Sumatra, having not been recorded since its original description almost 90 years ago from a museum specimen. The species is only known from its holotype (MSNG 32191) collected in 1891 and stored in alcohol. The specimen was collected from "Si-Rambé Forest" in North Sumatra (fide Vinciguerra, 1933), from which the exact locality cannot be traced today (Capocaccia 1961).

During explorations of the forests in northern Sumatra in June 2018, we collected one naturally dead specimen and observed one live specimen of the genus Harpesaurus. We could clearly attribute both specimens to the species $H$. modiglianii. The two specimens (one naturally dead and one live) we found are the second known records for the species and our following observations are the first data on the biology of this species. Here we re-describe the species based on its holotype which is compared with the newly discovered specimen which was naturally dead and discoloured. The discovery of the third specimen (the live specimen which was not collected), allowed us to provide further notes on the live colouration and the first data on its in-situ behaviour and natural history.

\section{Material and methods}

On 15 June 2018, during a field survey in the forests around the caldera of Toba supervolcano, North Sumatra Province, Indonesia (fig. 1), we found a dead agamid specimen on the forest floor that we could refer to the genus Harpesaurus. From its state of decomposition we concluded that the specimen had been dead for 2-3 days, although it still remained suitable for a through full morphological assessment. Curiously it was not eaten by a predator and the explanation for its death remains unknown. 
Examination showed it to be a male belonging to $H$. modiglianii. We preserved the whole specimen fixing in $10 \%$ buffered formalin prior to its storage in $70 \%$ ethanol. It was deposited in the Museum of Zoology, Research Center for Climate Change, University of Indonesia (UIMZ 0169). After a couple of days, we again extensively surveyed for 5 nights the habitats around the place where we found that dead specimen. On 18 June 2018 at 20:45 hr we found the first live specimen of $H$. modiglianii lying on a low branch, probably sleeping.

After photographing, the following morphometric characters were taken with a Mitutoyo digital calliper to the nearest $0.1 \mathrm{~mm}$, the specimen was released in the same habitat on the same night: snout-vent length (SVL, measured from tip of snout to anterior margin of vent), axilla-groin length ( $\mathrm{AG}$, distance between axilla and groin), head length (HL, distance between posterior edge of mandible and tip of snout), head width (HW, maximum width of head), head depth (HD, dorso-ventral distance between occiput and throat), eye-nostril length (EN, distance between anterior-most point of orbit and posterior border of nostril), snout length (ES, distance between anterior-most point of orbit and tip of snout), nasal appendage length (NAL, measured from tip of snout to tip of appendage), internarial distance (IN, shortest dorsal distance between inner margins of nares), orbit diameter (ED, horizontal largest diameter of orbit), interorbital width (IO, shortest distance between upper margins of orbits), eye to mandible length (MBE, distance between posterior-most point of orbit and posterior angle of the mandible bone), tympanum diameter (TYD, longest diameter of the tympanum), tympanum-eye length (TYE, distance between anterior-most margin of tympanum and posterior-most margin of orbit), upper arm length (UAL, distance between axilla and angle of elbow), lower-arm length (LAL, distance from elbow to wrist with both upper arm and palm flexed), palm length [PAL, distance between wrist (carpus) and tip of longest finger, with both palm and lower arm flexed], finger length [FL, from tip of finger, to the junction with the adjacent digit, excluding the claw (palmure)], femur length (FEL, distance between groin and knee), tibia length (TBL, distance between knee and heel, with both tibia and tarsus flexed), foot length (FOL, distance between heel and tip of longest toe, with both foot and tibia flexed) toe length (TL, from tip of toe, to the junction with the adjacent digit, excluding the claw), tail base width (TBW, largest diameter of tail base), tail length (TAL, measured entire tail from posterior margin of vent to tail tip).

Meristic characters were taken as follows: supralabials (SUP) and infralabials (INF), counted from first labial scale towards gape up to distinctly larger scale than the granular scales at gape on both sides; scales from eye to tympanum (ETS), count scale rows from posterior-most point of orbit to anterior-most point of tympanum; canthus rostralis scales (CR), counted from the first scale posterior to supranasal, to the end of supraciliary ridge; nuchal crest (NC), count number of spines on the dorsal head; dorsal spines (DS), count number of spines on the dorsal body from neck until the level of vent (in case of separate from nuchal crest); nuchal spines (NS), count number of spines on the dorsal head until neck (in case of separate from dorsal crest); dorso-nuchal spines (DNS), count number of spines on the dorsal head and body until the level of vent (in case of continuous nuchal and dorsal crest); tail spines (TS), count number of spines on the dorsal tail from the level of vent to tip of tail; midbody scales (MBS), count of scales around midbody (across whole body); ventral scales (VEN), counted from first scale posterior to mental (gular included), to last scale anterior to vent; subdigital lamellae on toe IV (SDL), from first proximal enlarged scansor wider than twice the width of the largest palm scale, to distalmost lamella at tip of digit.

Museum acronyms follow Uetz et al. (2019). Specimens of Harpesaurus were examined at the Muséum national d'histoire naturelle (Reptiles \& Amphibians), Paris, France (MNHN-RA); Museo Civico di Storia Naturale di Genova, Genova, Italy (MSNG); Zoologisches Forschungsmuseum Alexander Koenig, Bonn, Germany (ZFMK); and Museum of Zoology, Research Center for Climate Change, University of Indonesia (UIMZ). We used a Leicawild M3Z and a ZEISS DCR dissecting microscope to examine the external morphology of specimens and a Canon EOS 7D SLR digital camera to take photographs. The conservation status of the species was evaluated using the IUCN Standards and Petitions Subcommittee (2016): Version 12 guide was used to assess their risk of extinction.

Natural history observations were made by looking with the naked eye at the animal from a 
distance of at least 3-4 m, being careful not to disturb it.

Harpesaurus modiglianii Vinciguerra, 1933 (Figs 1-6; Tables 1, 2)

Holotype. Adult male, MSNG 32191, SVL 79.0 $\mathrm{mm}$, collected from Si-Rambé Forest, North Sumatra (foresta di Si-Rambé nella parte nord di Sumatra), Indonesia, by Dr. Elio Modigliani in 1891 (Capocaccia 1961). An English translation of the original description of $H$. modiglianii is provided (Appendix I), which was originally written in Italian.

Other specimen $(n=1)$. Adult male, UIMZ 0169 , Mt. Sibuatan Forested area $\left(2^{\circ} 52^{\prime} \mathrm{N}\right.$, $98^{\circ} 27^{\prime} \mathrm{E}$; alt. $1675 \mathrm{~m}$ a.s.l.) Lingga Raja, Pegagan Hilir, Dairi, North Sumatra, Indonesia, by C.A. Putra on 15 June 2018.

Redescription of holotype. A well preserved adult male specimen, SVL $79.0 \mathrm{~mm}$; head moderately large (HL $32.5 \%$ of SVL), elongate (HW $50.2 \%$ of HL), narrow (HW $16.3 \%$ of SVL), distinct from neck; snout long (ES 91.5\% of HW); snout length greater than orbit diameter (ES $196.7 \%$ of ED); interorbital distance broad (IO 38.5\% of HL); eye large (ED 23.3\% of HL); pupil rounded; ear-opening shallow and ovoid, its greatest diameter being dorsoventrally, with enlarged unkeeled scales anteriorly but not enlarged posteriorly; tympanum smaller than orbit (TYD 53.3\% of ED); no spines above the tympanum but three enlarged, keeled scales above, separated from the tympanum by a single smaller row of scales; diameter of eyes slightly greater than tympanum-eye distance (ED $109.1 \%$ of TYE); forehead concave; scales on snout slightly keeled, similar in size with those of the occipital region; scales on interorbital and supercilium area keeled; nuchal crest, 6 spines (among which first 5 enlarged); rostral scale width greater than height, posteriorly in contact with the first supralabial, in contact superiorly with the prenasal and four snout scales which forms the nasal appendage; the nasal appendage is pointed, elongate (NAL $94.1 \%$ of ES; NAL $43.2 \% \mathrm{HL}$ ), laterally flattened, covered with two rows of scales (a row of five enlarged scales interiorly and a row of six snout scales exteriorly); two elongated supranasals on each side, a single prenasal; nostril rounded and located in the middle of an undivided nasal plate; single postnasal; canthus rostralis and supraciliary edges sharp; parietal plate lozenge- shaped (anterior sides shorter than posterior sides), no "pineal eye", parietal plates larger than adjacent plates. Mental rhombus-shaped, its transversal width greater than its anteroposterior length, posteriorlaterally in contact with two enlarged postmentals (but smaller than mental) separated by a smaller scale preventing the contact between them. Gular fold short and its length approximately $25 \%$ of SVL, but dispersed and its depth approximately $75 \%$ of HD; chin, throat, and mid-gular area covered with smooth, overlapping, slightly acuminated scales; posterior part of lateral gular scales enlarged and slightly keeled; two scale rows separate orbit from supralabials; supralabials 8 $\left(6^{\text {th }}\right.$ located in mid orbit position, $3^{\text {rd }}-7^{\text {th }}$ larger in size); infralabials 8 , decreasing in size towards mouth gape.

Body slender (AG $44.6 \%$ of SVL); mid dorsal scales equal, keeled, mucronate, pointing backwards and upwards; scales on dorsum at midbody larger in size than those of venter at the symmetrical level; dorsal crest continuous stopping at mid-tail, 40 spines; lateral body scales enlarged, slightly keeled, mucronate, larger than dorsals, pointing backwards and downwards; 41 scales around midbody; pectoral scales equal, mucronate and keeled; abdominal scales not enlarged, keeled, and acuminated; ventral keels forming regular and parallel continuous ridges; no preanal or femoral pores. Ventrals, 84.

Upper arm greater than lower arm (UAL $107.6 \%$ of SVL; LAL $16.6 \%$ of SVL); femur greater than tibia (FEL $19.1 \%$ of SVL; TBL $17.3 \%$ of SVL; FEL $110.2 \%$ of TBL). Dorsal scales on fore and hind limbs enlarged, keeled, overlapping, and mucronate; ventral scales on upper and lower arm not enlarged, slightly keeled, overlapping, and mucronate; scales on dorsal and ventral surface of thigh slightly keeled, overlapping and mucronate; keels on dorsal and ventral arm and foot forming a series of continuous parallel ridges. Subdigital lamellae entire, 21 subdigital lamellae on the toe IV; relative length of fingers $3>4>5>2>1$, and toes $4>5>3>2>1$.

Tail complete; tail base swollen, scales on post cloacal area small, bluntly pointed and smooth; ventral scales on tail enlarged and strongly keeled; dorsal scales on tail slightly keeled, overlapping, directed straight backwards, keels forming continuous parallel ridges.

Colouration. In preserved specimen (holotype, fig. 2A). Dorsum bluish grey; snout, 


\section{Plate 01}

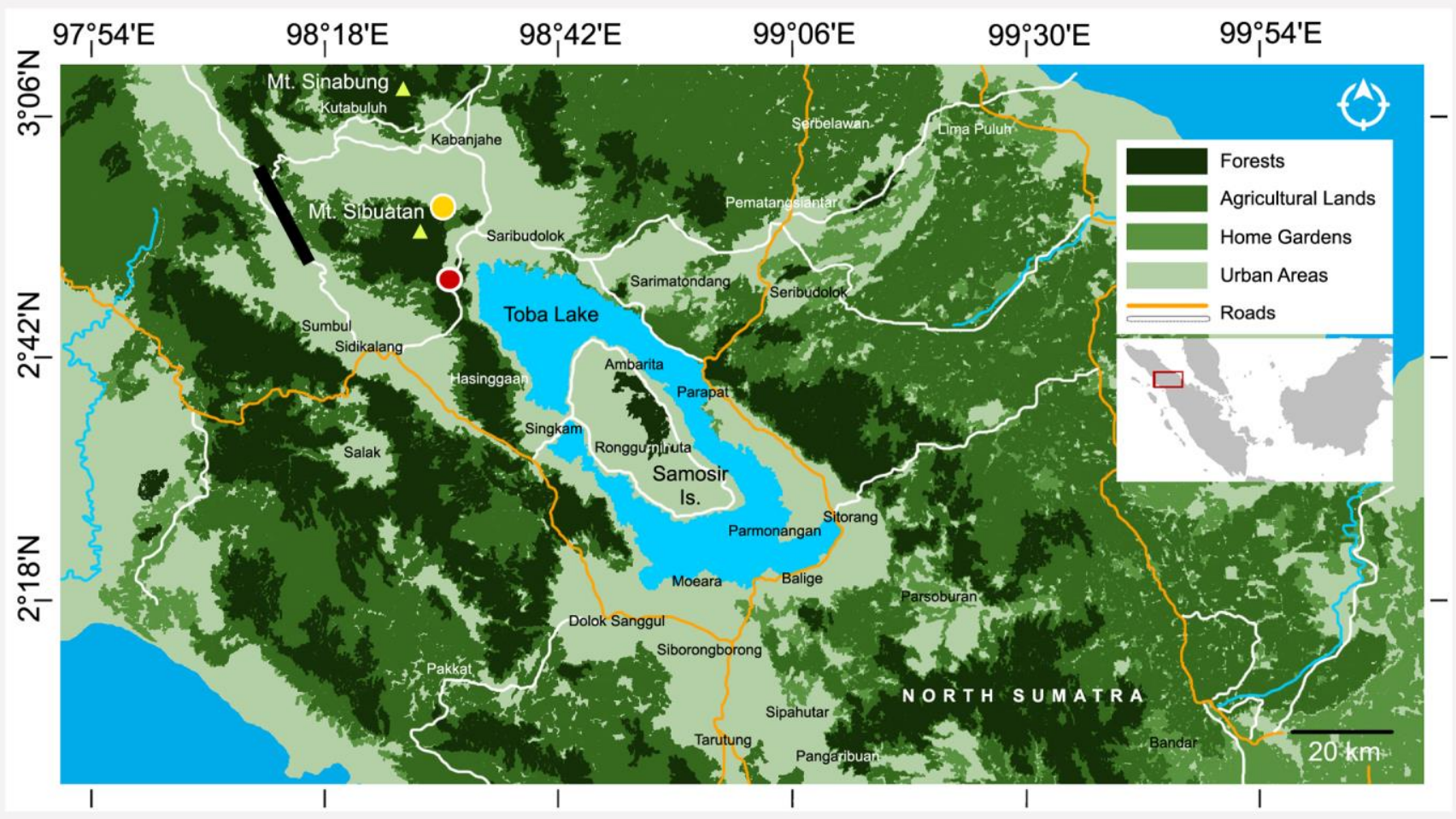

Figure 1. The distribution map of $H$. modiglianii in North Sumatra region: the red circle shows the location of the rediscovered specimen; the yellow circle is based on a photographic evidence shared in social media; the exact location of type locality is unknown.

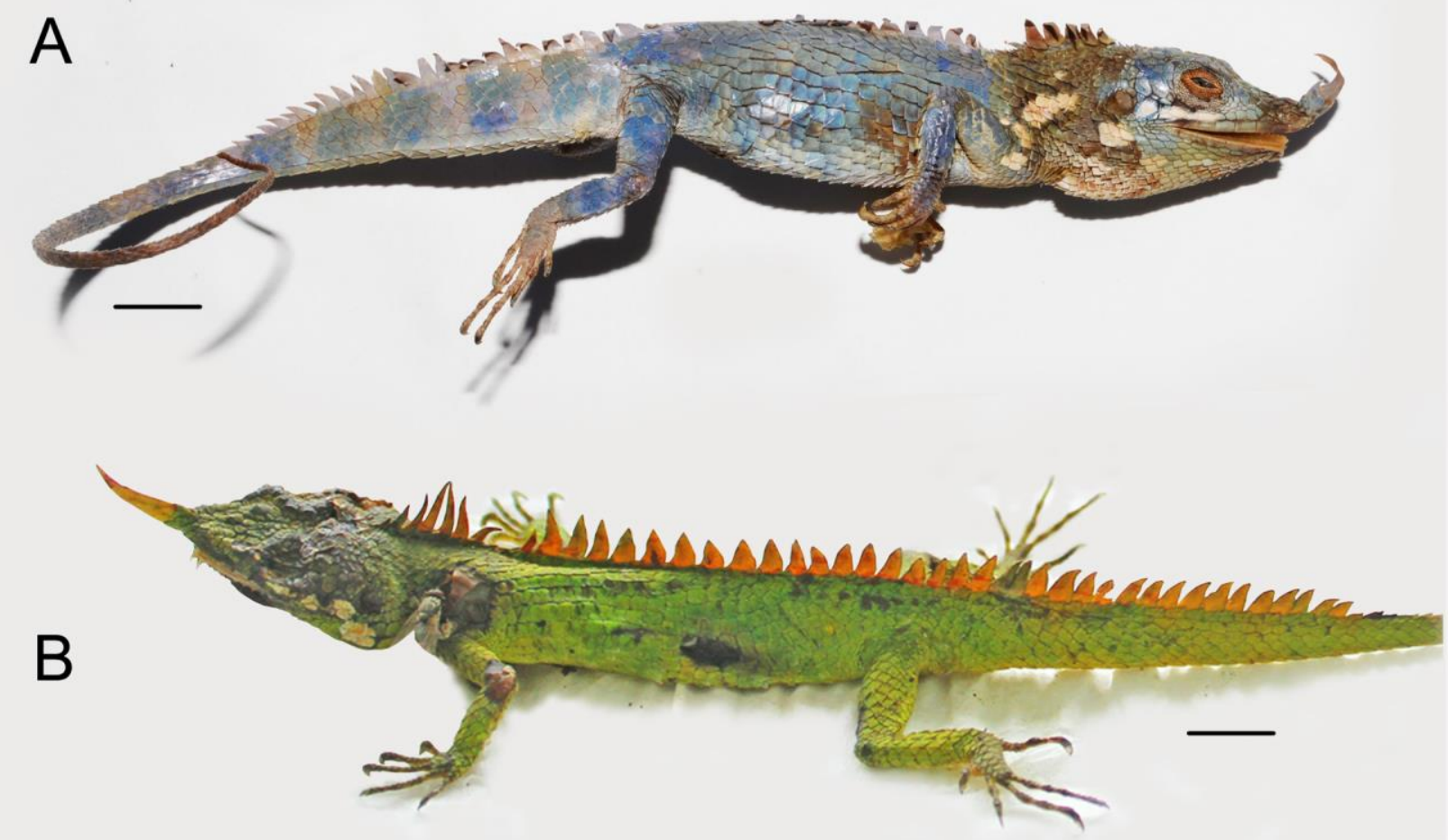

Figure 2. (A) Holotype male (79.0 mm SVL) of H. modiglianii (MSNG 32191) from Si-Rambé Forest in North Sumatra, collected in 1891; (B) Second specimen of $H$. modiglianii (UIMZ 0169), male (77.5 mm SVL) from Mt. Sibuatan Forested area in North Sumatra, collected in 2018 (Scale: $10 \mathrm{~mm}$ ). 
neck, nuchal area brownish; tail with distinct brownish bands; limbs, anterior flank, along vertebral area blue; venter light bluish white, while throat and pectoral area, palm and foot are dark cream; white patches on gular pouch, under the eye, and in the post tympanic area.

In life (based on new material; figs. 2B-4), dorsum uniform luminous green; venter and dorsal spines yellowish green; four chestnut colour patches under the eye, under the tympanum, on the shoulder, and upper arm. Figure 4 represents the same individual in undisturbed situation (before capturing, fig. 4A), and disturbed situation (after capturing, fig. 4B)
Natural History. The elevation of the moist forest area we surveyed was $1,675 \mathrm{~m}$ a.s.l. and the air temperature was cold. No nearby stream was observed at the survey site, but a seasonal pool was present around $1 \mathrm{~km}$ away from the location. The weather was misty in the morning and windy for the rest of the day until late afternoon on both days of observation. The habitat was wet due to the rainy season (JuneJuly). The canopy was dominated by large trees, but there were many open places under a midlayer of medium size trees covered with mosses; the forest floor was mostly leaf litter and moss (fig. 5A).

Table 1. Morphometric and meristic character comparison of some Harpesaurus species, based on available museum specimens (Appendix II); holotype of H. ensicauda is lost (fide Hallermann 1998); “-_" unknown.

\begin{tabular}{|c|c|c|c|c|c|}
\hline \multirow{3}{*}{ character } & \multicolumn{5}{|c|}{ Male } \\
\hline & \multicolumn{2}{|c|}{ H. modiglianii } & \multirow{2}{*}{$\begin{array}{c}\text { H. beccarii } \\
\text { ZFMK } 48896 \\
\text { (Böhme 1989) }\end{array}$} & \multirow{2}{*}{$\begin{array}{c}\text { H. ensicauda } \\
\text { Based on } \\
\text { Werner (1913) }\end{array}$} & \multirow{2}{*}{$\begin{array}{c}\text { H. tricinctus } \\
\begin{array}{c}\text { MNHN-RA } 0623 \\
\text { holotype }\end{array}\end{array}$} \\
\hline & $\begin{array}{c}\text { MSNG } 32191 \\
\text { holotype }\end{array}$ & $\begin{array}{c}\text { UIMZ } 0169 \\
\text { new material }\end{array}$ & & & \\
\hline SVL & 79.0 & 77.5 & 80.0 & 60.0 & 60.0 \\
\hline AG & 35.2 & 39.9 & 45.4 & - & 29.3 \\
\hline HL & 25.7 & 24.0 & 21.2 & 14.0 & 17.4 \\
\hline HW & 12.9 & 12.7 & 11.5 & 7.0 & 8.9 \\
\hline HD & 15.4 & 10.0 & 12.5 & - & 8.6 \\
\hline TYE & 5.5 & 5.0 & 5.1 & - & 4.4 \\
\hline TYD & 3.2 & 2.8 & 3.1 & - & 1.1 \\
\hline ED & 6.0 & 5.2 & 4.7 & - & 5.1 \\
\hline EN & 8.4 & 7.9 & 6.9 & - & 4.8 \\
\hline ES & 11.8 & 10.4 & 10.5 & - & 6.9 \\
\hline NAL & $\begin{array}{c}11.1 \\
\text { (single) }\end{array}$ & $\begin{array}{c}12.1 \\
\text { (single) }\end{array}$ & $\begin{array}{l}4.7,4.1 \\
\text { (couple) }\end{array}$ & - & $\begin{array}{c}22.0 \\
\text { (single) }\end{array}$ \\
\hline IN & 3.9 & 3.9 & 3.1 & - & 2.3 \\
\hline IO & 9.9 & 6.9 & 9.3 & - & 4.5 \\
\hline FEL & 15.1 & 14.6 & 15.4 & - & 11.0 \\
\hline TBL & 13.7 & 13.2 & 14.2 & - & 9.7 \\
\hline FOL & 17.6 & 17.9 & 14.3 & - & 11.0 \\
\hline TL IV & 10.9 & 9.8 & 9.2 & - & 4.4 \\
\hline UAL & 14.1 & 13.9 & 11.5 & - & 9.4 \\
\hline LAL & 13.1 & 12.7 & 12.0 & - & 9.3 \\
\hline PAL & 10.2 & 10.2 & 9.7 & - & 8.5 \\
\hline TBW & 7.2 & 5.0 & 5.5 & - & 3.5 \\
\hline TAL & 135.0 & 135.0 & 151.0 & 60.0 & 86.0 \\
\hline SUP & 7 & 8 & 8 & - & 8 \\
\hline ETS & 4 & 4 & 5 & - & 9 \\
\hline $\mathrm{CR}$ & 4 & 4 & 4 & - & 4 \\
\hline $\mathrm{NC}$ & 6 & 6 & 9 & 0 & 8 \\
\hline DS & 18 & 17 & 13 & 0 & 22 \\
\hline TS & 22 & 18 & 16 & 0 & $40+$ \\
\hline MBS & 41 & 39 & 53 & - & 41 \\
\hline VEN & 84 & 86 & 82 & - & 100 \\
\hline SDL on T4 & (R 22, L 21) & 22 & 22 & - & 21 \\
\hline
\end{tabular}


Table 2. Diagnostic characters among some Harpesaurus species, based on museum specimens (Appendix II) and/or original descriptions; "-_" unknown.

\begin{tabular}{lcccc}
\hline \multicolumn{1}{c}{ Character } & H. modiglianii & H. beccarii & H. ensicauda & H. tricinctus \\
\hline SVL & 79.0 & 80.0 & 60.0 & 60.0 \\
HL/AG & $73 \%$ & $47 \%$ & - & $59 \%$ \\
NAL/HL & $43 \%$ & $22 \%$ & - & $126 \%$ \\
SVL/TAL & $58 \%$ & $53 \%$ & $100 \%$ & $70 \%$ \\
Number of nasal appendages & single & couple & single & single \\
ETS & 4 & 5 & - & 9 \\
Number of nuchal crest spines & 6 & 9 & 0 & 8 \\
Number of dorsal + tail spines & 40 & 29 & 0 & $62+$ \\
Number of ventral scales & 84 & 82 & - & 100 \\
Continuation of tail spines & $50 \%<$ of TAL & $\sim 20 \%$ of TAL & - & $100 \%$ of TAL \\
Lateral body scales & enlarged & Not-enlarged & - & Not-enlarged \\
Inter-orbital scales & Not-enlarged & enlarged & enlarged & Not-enlarged \\
\hline
\end{tabular}

When we found the living $H$. modiglianii, it was on a horizontal tree branch $(3 \mathrm{~cm}$ diameter) approximately $4 \mathrm{~m}$ above the ground, and it was keeping the head downwards. When it was kept for a while in captivity on a tree branch, it moved slowly on that tree branch. Shortly after capture, the animal showed waggling locomotion behaviour similar to chameleons, and rapidly hid behind branches and the body colour suddenly turned to greenish brown and the chestnut coloured patches turned to white. Within a few minutes, the yellowish green spines and venter turned to a chestnut colour (fig. 4B). After relaxing, it returned its body colour to its original green, which most likely is the colour adopted when not stressed. Our observation confirms that the species is diurnal and arboreal. Convergence in behaviour and physiology of skin colour with African mountain chameleons is striking and reflects a deep arboreal specialisation.

Conservation status. The species has been previously assessed as Data Deficient (DD) by the IUCN, and this new data has allowed a more precise assessment of its extinction risk. The application of the IUCN Red List criteria (2016: version 12) shows that $H$. modiglianii is Endangered (EN) as it is restricted to an area of occupancy (AOO) of $8-12 \mathrm{~km}^{2}$ where two individuals were recorded within $500 \mathrm{~m}$ distance (our observations), and a third individual within $20 \mathrm{~km}$ distance, based on photographic evidence shared in social media. We summarize the known distribution on a map (fig. 1). The habitat where our two recent specimens were observed is in moderately high-elevation forest, but outside protected areas. That forest is highly threatened by large scale exploitation including clear cutting, and the habitat is highly disturbed by heavy machines (fig. 5B).

\section{Discussion}

The systematics of the Southeast Asian radiation of arboreal agamids is poorly understood and in need of precise molecular studies in order to attribute correct generic assignment to the recognized species. The definition and content of the genus Harpesaurus remains uncertain following the above-summarised taxonomic actions (Böhme 1989).

Meiri et al. (2018) highlighted that $14 \%$ of lizard diversity is restricted to a single locality, often in inaccessible regions. Since many face severe extinction risk, while current knowledge is inadequate to properly assess their conservation status, Meiri et al. (2018) recommended that such species become the focus of taxonomic, ecological and survey efforts. Extensive field work and sampling of Indonesian arboreal agamids, especially those living at high altitudinal isolated mountains in Sumatra, are necessary and should be the focus of modern field research. Land management authorities should consider protecting the habitat of $H$. modiglianii and other such rare mountain taxa, and rigorously enforce existing laws, especially those relating to logging. We have observed some attempts of trading of this species via social media applications, and the local traders offer this species for USD 100 per individual. Most of the captured individuals by the traders were fully grown adult males, captured from forested areas around Berastagi (1,300 $\mathrm{m}$ a.s.l.). Considering the current habitat destruction and threats from pet traders we highlight the conservation urgency for relevant 


\section{Plate 02}
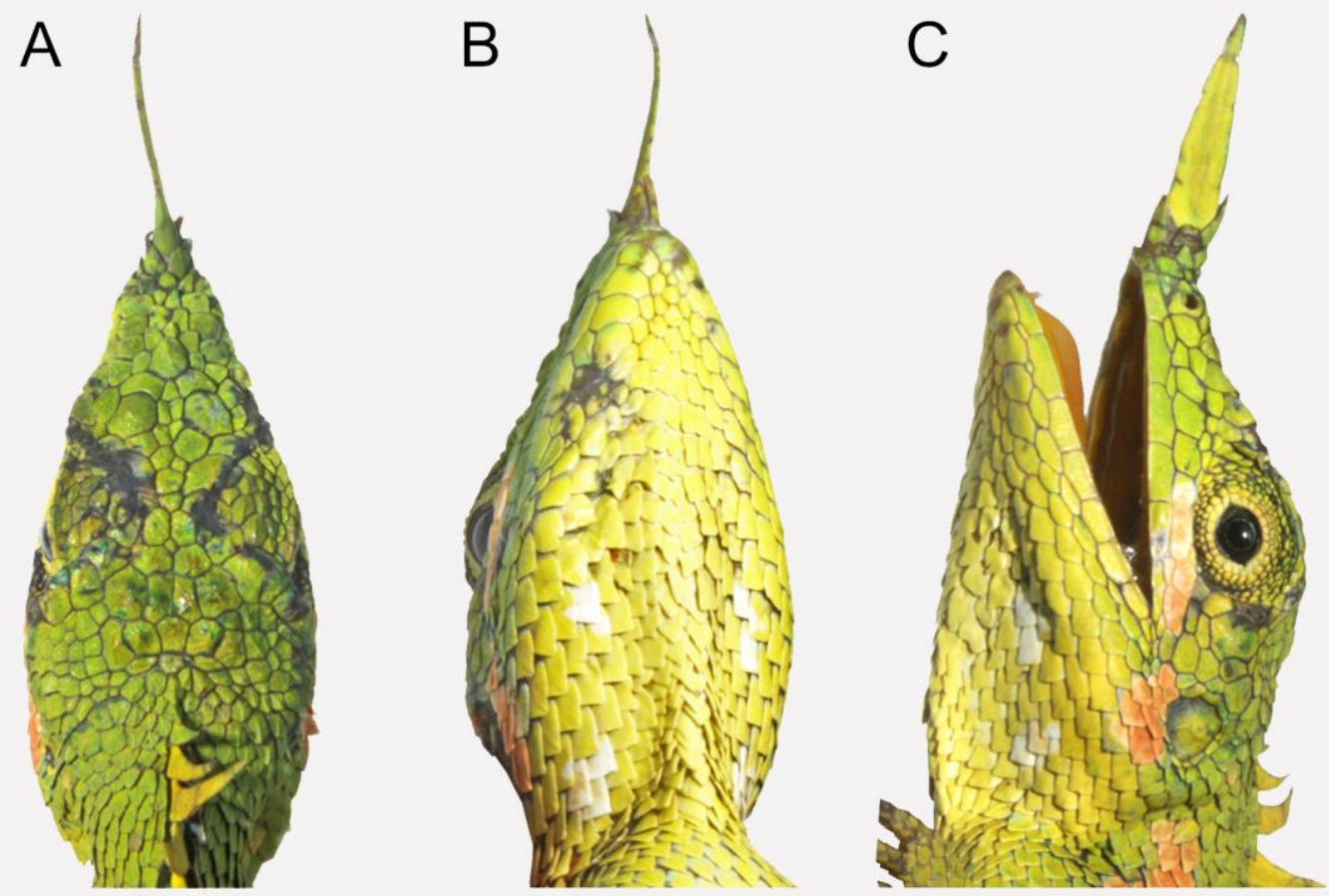

Figure 3. H. modiglianii (not collected) live adult male at $1,675 \mathrm{~m}$ elevation of Mt. Sibuatan Forested area, North Sumatra, Indonesia; (A) dorsal head view; (B) ventral head view; (C) lateral head view (left).
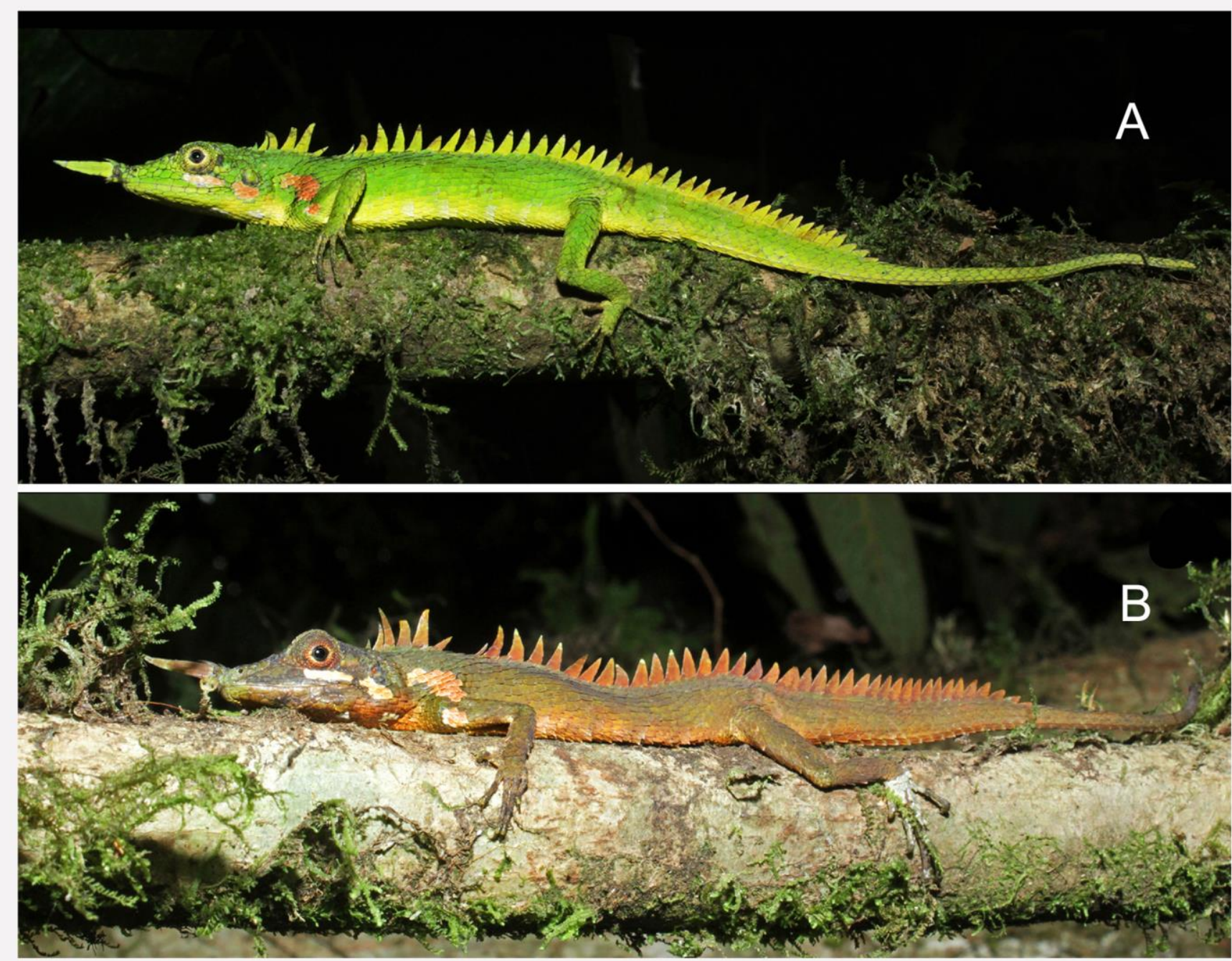

Figure 4. H. modiglianii (not collected) live adult male at 1,675 m elevations of Mt. Sibuatan Forested area; general body coloration (A) before capturing (undisturbed situation); (B) after capturing (disturbed situation). 


\section{Plate 03}
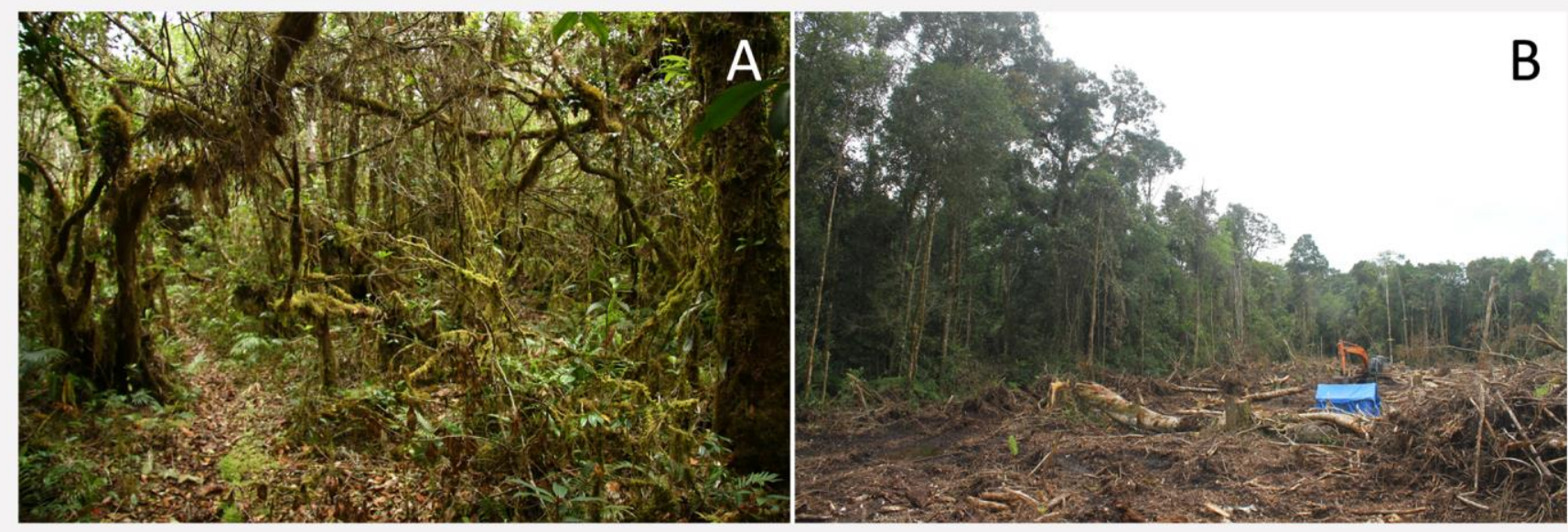

Figure 5. (A) Habitat of $H$. modiglianii where the live specimen was found, (B) clearcutting near the species' habitat.

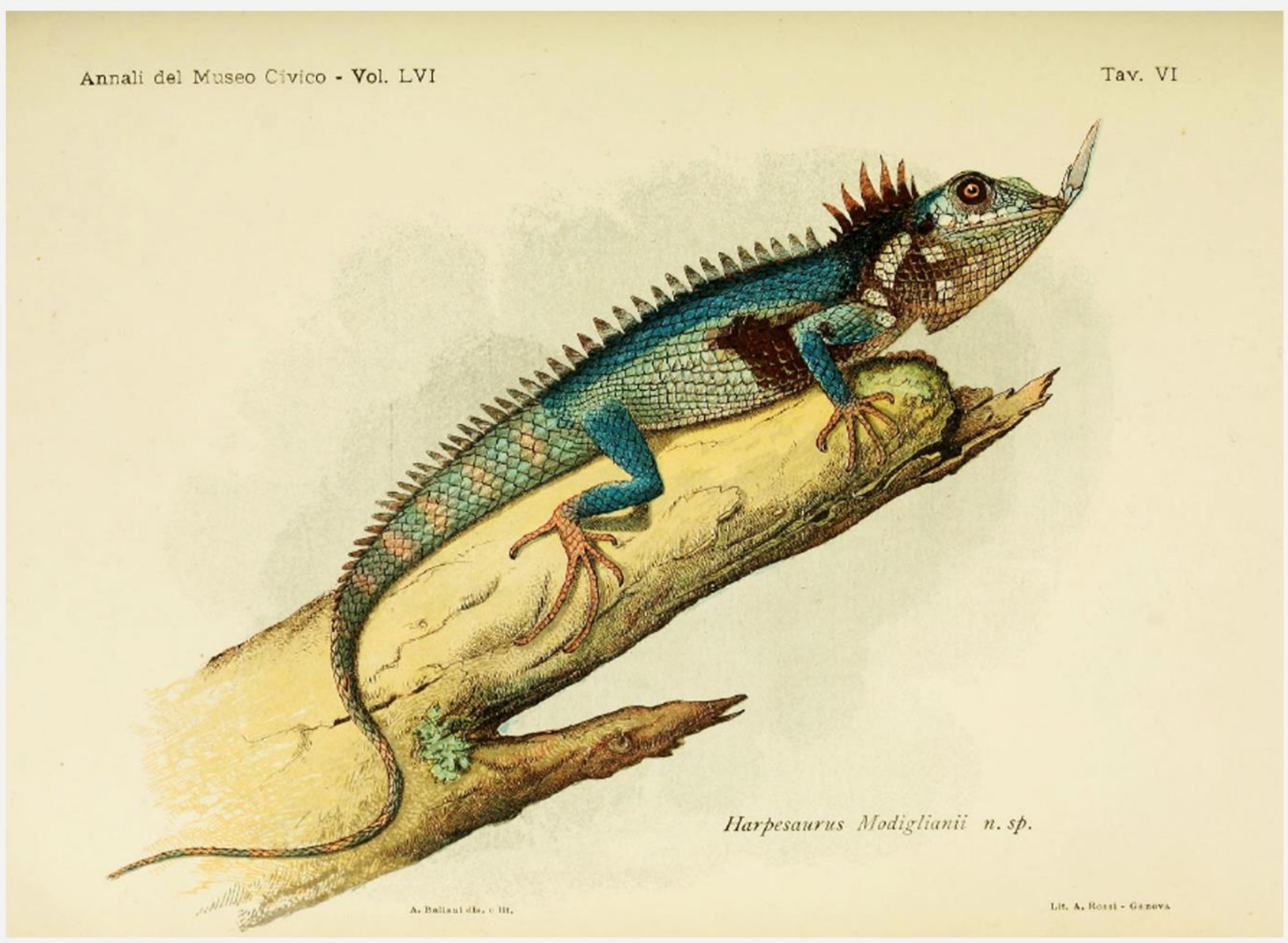

Figure 6. The original figure of $H$. modiglianii illustrated by Armando Baliani; reprinted from Vinciguerra, 1933 (Annali del Museo civico di storia naturale di Genova 56, pl. VI). 
government authorities, especially here we propose to include this species into the list of protected species (P.106) of the regulation of the ministry of environment and forestry, Republic of Indonesia (Nomor P.106 / MENLHK / SETJEN / KUM.1/12/2018).

\section{Acknowledgements}

We are grateful to D. Arfianto, P. Sitorus, and the community of Herpetologer Mania for their support during our field work. We also would like to thank, Lee Harding (Canada) and Chris Margules (James Cook University, Australia) for their valuable comments, and Marinus S. Hoogmoed (Museu Paraense Emilio Goeldi, Brazil), and René W.R.J. Dekker (Natural History Museum, London) for their support.

\section{Literature cited}

Amarasinghe, A.A.T., M.B. Harvey, A. Riyanto, and E.N. Smith (2015). A new species of Cnemaspis (Reptilia: Gekkonidae) from Sumatra, Indonesia. Herpetologica, 71 (2): 160-167.

Böhme, W. (1989). Rediscovery of the Sumatran agamid lizard Harpesaurus beccarii Doria 1888 , with the first notes on a live specimen. Tropical Zoology, 2: 31-35.

Boulanger, G.A. (1885). Catalogue of the Lizards in the British Museum (Natural History). British Museum (Natural History), London: $436 \mathrm{pp}$.

Capocaccia, L. (1961). Catalogo dei tipi di Rettili del Museo Civico di Storia Naturale di Genova [MSNG]. Annali del Museo civico di storia naturale Giacomo Doria, 72: 86-111.

Doria, G. (1888). Note Erpetologiche - Alcuni nuovi Sauri raccolti in Sumatra dal Dr. O. Beccari. Annali del Museo civico di storia naturale di Genova, 2 (ser. 6): 646-652.

Duméril, A.H.A. (1851). Note sur un nouveau genre de la famille des Reptiles Iguaniens acrodontes. Revue et Magasin de Zoologie: 213-217.

Duméril, A.M.C. and A.H.A. Duméril (1851). Catalogue méthodique de la collection des reptiles du Muséum d'Histoire Naturelle de Paris. Gide et Baudry/Roret, Paris: 224 pp.

Grismer, L.L., A. Riyanto, D. Iskandar, and J.A. McGuire (2014). A new species of Hemiphyllodactylus Bleeker, 1860 (Squamata: Gekkonidae) from Pulau Enggano, southwestern Sumatra, Indonesia. Zootaxa 3821 (4): 485-495.

Harvey, M.B., A. Hamidy, N. Kurniawan, K. Shaney, and E.N. Smith (2014). Three new species of Pseudocalotes (Squamata: Agamidae) from southern Sumatra, Indonesia. Zootaxa, 3841 (2): 211-238.

Harvey, M.B., K.A. O’Connell, G. Barraza, A. Riynto, N. Kurniwan et al. (2015). Two new species of Cyrtodactylus (Squamata: Gekkonidae) from the southern Bukit Barisan range of Sumatra and an estimation of their phylogeny. Zootaxa, 4020 (3): 495-516.

Harvey, M.B., K. Shaney, A. Hamidy, N. Kurniawan, and E.N. Smith (2017a). A new species of Pseudocalotes (Squamata: Agamidae) from the Bukit Barisan range of Sumatra with an estimation of its phylogeny. Zootaxa, 4276 (2): 215-232.

Harvey, M.B., K. Shaney, I. Sidik, N. Kurniawan, and E.N. Smith (2017b). Endemic dragons of Sumatra's volcanoes: new species of Dendragama (Squamata: Agamidae) and status of Salea rosaceum Thominot. Herpetological Monograph, 31 (1): 69-97.

Harvey, M.B., J. Scrivani, K. Shaney, A. Hamidy, N. Kurniawan et al. (2018). Sumatra's endemic crested dragons (Agamidae: Lophocalotes): a new species from the Bukit Barisan range, comments on Lophocalotes ludekingi, and ecology. Herpetologica, 74 (1): 73-88.

Iskandar, D.T., J.A. McGuire, and A.A.T. Amarasinghe (2017). Description of five new day geckos of Cnemaspis kandiana Group (Sauria: Gekkonidae) from Sumatra and Mentawai archipelago, Indonesia. Journal of Herpetology, 51 (1): 142-153.

Iskandar, D.T. and Mumpuni (2004). A new toad of the genus Ansonia (Amphibia, Anura, Bufonidae) from Sumatra, Indonesia. Hamadryad, 28: 59-65.

IUCN Standards and Petitions Subcommittee (2016). Guidelines for using the IUCN Red List Categories and Criteria. Version 12. Prepared by the Standards and Petitions Subcommittee, IUCN, $101 \mathrm{pp}$.

King, F.W. (1978). A new Bornean lizard of the genus Harpesaurus. The Sarawak Museum Journal, 1978: 205-209.

Lardner, B., S.Y. Chin, and U. Manthey (2010). Notes on Harpesaurus borneensis Mertens (1924), a live bearing agamid lizard from the lowlands of Borneo. Russian Journal of Herpetology, 17 (3): 231-235.

Manthey, U. (2010). Agamid Lizards of Southern Asia. Draconinae 2 - Leiolepidinae. Terralog 7b, Edition Chimaira, Frankfurt am Main, 168 pp.

Meiri, S., A.M. Bauer, A. Allison, F. CastroHerrera, L. Chirio et al. (2018). Extinct, 
obscure or imaginary: the lizard species with the smallest ranges. Diversity and Distributions, 24 (2): 262-273.

Mertens, R. (1924). Über einige Reptilien aus Borneo. Zoologischer Anzeiger, 60: 155-159.

Moody, D.M. (1984). Rediscovery of Hylagama borneensis Mertens 1924 (Reptilia; Lacertilia; Agamidae). Ms, 8 pp.

Parker, H.W. (1924). Description of a new agamid lizard from Sumatra. Annals and Magazine of Natural History, 9 (24): 624-625.

Richman, N. and M. Böhm (2010). Harpesaurus modigliani. The IUCN Red List of Threatened Species 2010: e.T170400A6776835. Downloaded on 25 October 2019.

Schlüter, A. and J. Hallermann (1997). The type specimens in the herpetological collection of the Staatliches Museum für Naturkunde in Stuttgart. Stuttgarter Beiträge zur Naturkunde. Serie A, 553: 1-15.
Teynié, A., P. David, and A. Ohler (2010). Note on a collection of amphibians and reptiles from western Sumatra (Indonesia), with the description of a new species of the genus Bufo. Zootaxa, 2416: 1-43.

Uetz, P., S. Cherikh, G. Shea, I. Ineich, P.D. Campbell et al. (2019). A global catalog of primary reptile type specimens. Zootaxa, 4695 (5): 438-450.

Vinciguerra, D. (1933). Descrizione di una nuova specie di Harpesaurus di Sumatra. Annali del Museo civico di storia naturale di Genova, 56: 355-357.

Wermuth, H. (1967). Liste der rezenten Amphibien und Reptilien: Agamidae. Das Tierreich, 86: $1-127$.

Werner, F. (1913). Neue oder seltene Reptilien und Frösche des Naturhistorischen Museums in Hamburg. Jahrbuch der Hamburgischen Wissenschaftlichen Anstalten, 30 (2): 1-39.

Appendix I. English translation of the original description of $H$. modiglianii Vinciguerra, 1933.

\section{DESCRIPTION OF A NEW SPECIES OF HARPESAURUS FROM SUMATRA BY D. VINCIGUERRA}

(Plate VI).

The rich herpetological material carried by Dr. Elio Modigliani during his travels, not yet completely illustrated, includes a notable lizard that is worth to be known. It was quickly identified by Marquis Giacomo Doria as a new species of Harpesaurus and it was assigned to the name H. Modiglianii, but this name was unpublished. Thus, I thought it was necessary to describe this reptile maintaining the name chosen by the prominent museum founder.

Three species belonging to the genus Harpesaurus, characterized by a sickle-shaped appendix, are already known: one form Java, one from Sumatra, and one from Nias. The first one was described by A. Dumeril in 1851 and it was named tricinctus $\left(^{1}\right)$, assigning it to the genus Arpephorus, already used by Fischer de Waldheim for a beetle, and it is characterized by small equal dorsal scales arranged in series; the second one is $H$. Beccarii $\left(^{2}\right)$, described by Doria with a double nasal appendix and rhomboidal scales; the third one is $H$. ensicauda $\left(^{3}\right)$, lacking the dorsal crest and with smooth scales.

Recently, a fourth species was described by Parker for this genus, under the name Thaumatorhynchus Brooksi, $\left({ }^{4}\right)$ coming from Sumatra (Benculen) and having a gular sac, small keeled dorsal scales, cylindrical rostral appendix, 12 o 13 superior labials, dorsal crest represented by an indefinite series of large keeled scales, and the nuchal one formed by 7 small separated triangular scales.

This species is similar to Modiglianii because of the presence of a small gular sac, but it can be distinguished by the cylindrical and not compressed nasal appendix. Other species of lizards having a nasal appendix are the Ceratophora from Ceylon which can be distinguished by the lack of tympanum.

This is the description of this new Harpesaurus.

${ }^{1}$ ) A. Dumeril. Cat. Méth. Rept. 1851, pag. 93.

${ }^{2}$ ) Doria. Ann. Mus. Civ. Genova, vol. XXVI, pag. 646. tav. VIII, fig. 2.

(3) Werner, Mitt. Natur. Mus. Hamburg XXX, pag. 8.

( $\left.{ }^{4}\right)$ Parker H. W. - Ann. \& Mag. of Nat. Hist., Ninth. Ser. vol. XIV, 1924, pag. 624, fig. pag. 625 


\section{Harpesaurus Modiglianii n. sp.}

Rostral appendix as long as the head, simple, formed by a sickle-shaped compressed scale, upward and with its basis surrounded by some rather large scales. Head with medium-sized irregular scales and with erratic tubercles, partly polygonal. Lower rostral with a marked rostral angle. Nostrils located in an elongated scale, separated by the rostral scale by a smaller scale. Tympanum a little smaller than the eye. Eight upper and seven lower labials. Projecting snout. Nuchal crest formed by 7 scales, the 4th one being longer but lower than the back, separated by the dorsal crest by a small gap. Body compressed, with a crest extending from the nape to the tail half much lower than the nuchal one, and covered by large keeled scales in irregular series. Ventral scales heavily keeled. Keeled legs scales, with the exception of fingers. Long compressed tail with two series of keeled scales.

Body coloration blue, with white spots on head sides, more evident on the right side. Fourth or fifth upper labial scales white colored. Small gular sac. Dark nuchal crest and head sides; a dark spot on the anterior part of the thorax. Tail with indefinite reddish patches.

SVL without rostral appendix $83 \mathrm{~mm}$

Tail length $139 \mathrm{~mm}$

Rostral appendix length $6 \mathrm{~mm}$

This species is dedicated to the famous explorer, recently passed away, who discovered it in the SiRambé Forest in the northern part of Sumatra.

I want to acknowledge my friend Armando Baliani for the beautiful and the accurate lithographic reproduction of this elegant species.

Appendix II. Other specimens examined

Harpesaurus beccarii (1 ex.): Sumatra: Sidjungjung: ZFMK 48896

H. modiglianii (2 ex.): Sumatra: Si Rambé: MSNG 32191 (holotype); Mt. Sibuatan: UIMZ 0169

H. tricinctus (1 ex.): Java?: MNHN-RA 0623 (holotype by monotypy) 
- blank page - 